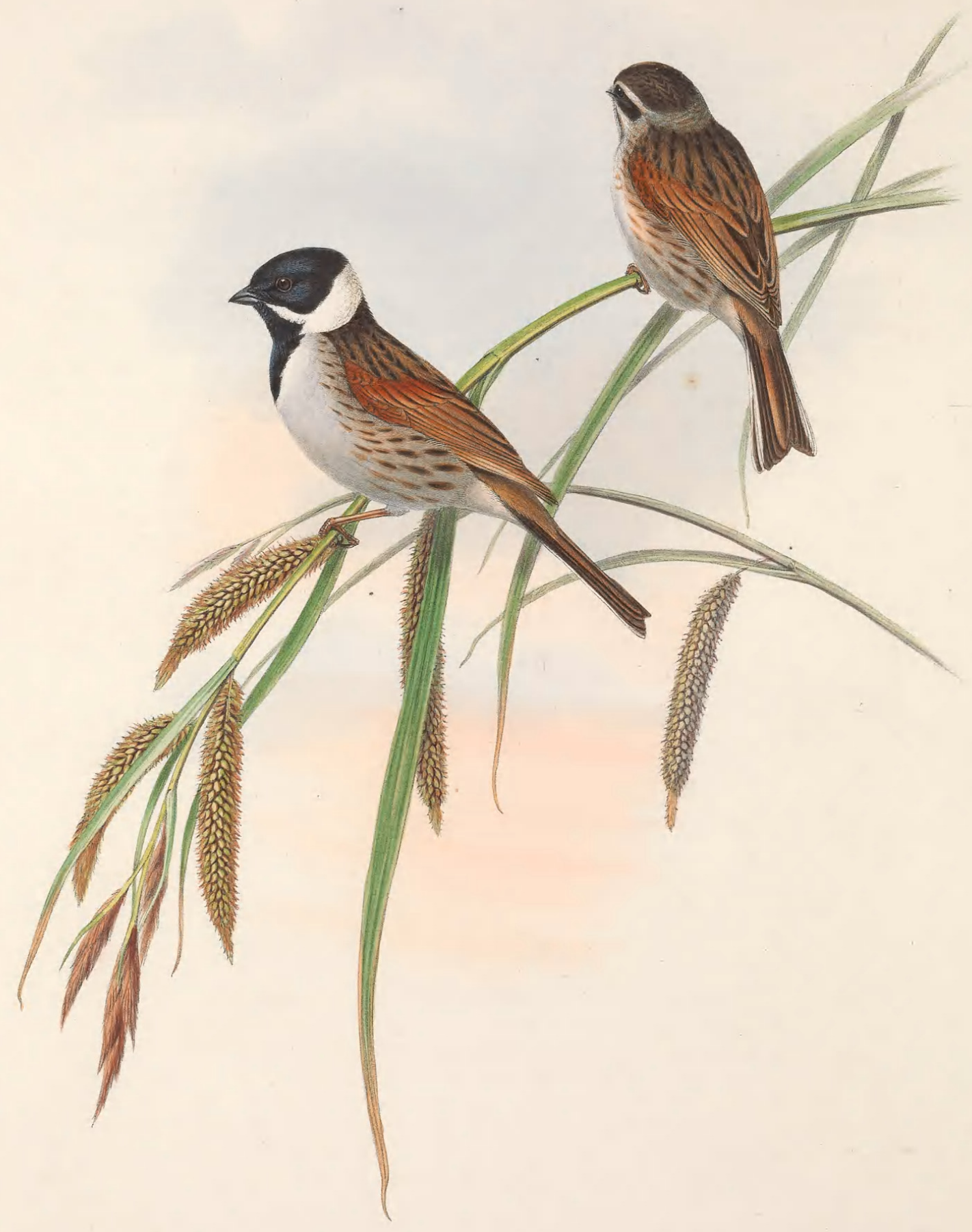




\section{SCHANICOLA ARUNDINACEA.}

\section{Reed-Bunting.}

Emberiza Schaniclus, Linn. Syst. Nat., tom. i. p. 311.

arundinacea, Gmel. Edit. Linn. Syst. Nat., tom. i. p. 881.

passerina, Pall. Zoogr. Ross.-Asiat., tom. ii. p. 49 ?

Scheniculus, Flem. Brit. Anim., p. 78.

Cynchramus Schaniclus, Boie, Isis, 1826, p. 974.

stagnatilis et septentrionalis, Brehm, Handb. der Naturg. Vög. Deutsch., pp. 301, 302.

Hortulanus arundinaceus, Briss. Orn., tom. iii. p. 274.

Schaenicola arundinacea, Bonap. Consp. Gen. Av., tom. i. p. 463, Schaenicola, sp. 1.

However much some persons may be disposed to carp at what they consider an undue division of the older genera, and the consequent establishment of new ones, I, for one, believe that the practice, when judiciously exercised, has a beneficial rather than an injurious influence upon the study of natural history. Thus to keep all the Buntings under one generic appellation, as was formerly done by Temminck and others, would rather embarrass than assist us in the investigation of that family of birds. No one who has studied our native birds can have failed to observe the very great difference in appearance between the Corn-Bunting (Cynchramus miliaria) with its uniform colouring, the beautiful Yellow-Hammer (Emberiza citrinella) with its gay dress, and the Reed-Bunting (Schcenicola arundinacea) with its black head and white neck-collar; or that these variations in colouring are accompanied by a corresponding diversity of structure, and that, besides differing in colour and form, they also differ in their habits and mode of life, each to a certain extent affecting different situations in the countries they respectively inhabit, and each being beautifully adapted to fulfil the specific office for which they were created. The Corn-Bunting resorts to arable lands and arid wastes, the Yellow-Hammer to the hedgerow, and the Reed-Bunting to the fluviatile portions of the country. Of these three species, or at least two of them, many representatives, constructed in precisely the same form, and having a similar style of colouring and markings, are found in other parts of the world. Surely then it becomes necessary that they should not be all arranged under one generic title, but that each form should have a designation of its own by which it may be at once recognized : this has accordingly been done by modern systematists.

I have mentioned that the Reed-Bunting resorts to fluviatile districts; and I may now add that it especially affects bogs, marshes, broads, and the basins of rivers, particularly where the common reed (Phragmites communis) grows, and osiers, alders, and willows abound. On the banks of the Thames and all its tributaries, in the fens of Lincolnshire, Cambridgeshire, Norfolk, and Suffolk, and in all situations where rank vegetation clothes the sides of water, from one end of England and Wales to the other, the bird is found. In Ireland it is a resident species, that island, from the prevailing humidity, remarks Thompson, being well suited to it. In Scotland it is scarcely less abundant. In the marshy countries of Holland and Belgium no bird is more frequently met with; neither is it much less numerous in Germany and all the central parts of Europe. It also ranges far to the north, in Norway and Sweden. Captain Loche informs us that it is found in Algeria; but it was not noticed there by Mr. Tristram and his friends, nor does that gentleman include it in his list of the birds of Palestine.

I cannot agree with Macgillivray and some other of my cotemporaries when they describe this bird as shy and difficult of approach; for I and all my fellow-fishermen, and, indeed, every one who whiles away a pleasant hour on the Thames, find it just the reverse. What bird, in fact, which frequents the banks of that beautiful river can be more nearly approached, or which sits more conspicuously on the hanging branch of the willow or the upright stem of the osier? Where is there a bird which allows you to get so near while it is in search of stranded seeds, insects, or small mollusks on the margins of the water, or while similarly - occupied on the hard-trodden towing-path? All who have visited such localities must have noticed the white-necked male flit before them with a jerking flight, or cross the river at right angles to the neighbouring ait.

In Scotland this bird is said to leave the country during the winter, or, at all events, to become sensibly scarcer at that period; with us on the Thames, and, I believe, in all our central and southern counties, it is as abundant in winter as in summer. The greater number remain near water; but a few occasionally seek the hedges of the open fallow or grass fields, and, like other birds, when driven to a strait for food, it will resort to the farm-yard; not that grain under ordinary circumstances is an article of its diet, its feeble bill being better adapted for the seizure of insects, small seeds, and minute shelled mollusks, all of which are readily found in its usual places of resort, the marsh and the willow-bed. 
Few birds offer a more marked difference in the colouring of the sexes than the Reed-Bunting; for the female has neither the black head nor the white collar which form such conspicuous features in the male, and which render him so ornamental an object amid the surrounding foliage. As spring draws near, this black hue of the head becomes more intense, and the white of the nuchal band more pure; in winter, on the other hand, all the feathers are tipped with brown, the abrasion of which, in the following spring, leaves them jet black.

The presence of the bird is at all times made manifest by its somewhat monotonous feeble chirp; but it occasionally utters a lengthened, agreeable, inward song, which I always listen to with pleasure, as I presume do all who hear it.

When the osiers have put forth their shoots, and the flags of the marsh grown sufficiently high to screen the nest from observation, the Reed-Bunting commences the task of incubation, and generally places its cup-shaped structure on the ground, on the stub of a willow, or on the side of a bank. The nest is composed of fine grasses, with a slight lining of long hairs. The eggs are four or five in number, of a pale stone-colour, with large unfrequent blotches and scribblings, as it were, of deep umber-brown, bounded by a suffusion of a paler tint, appearing as if the markings had been laid on and the colour had slightly spread over the neighbouring surface. The eggs are in length about twelve sixteenths of an inch, and in breadth nine sixteenths, or rather less than those of the Yellow Hammer and Ortolan. The breeding-season lasts from the beginning of May until August, during which two broods are usually produced, the first during the early part of the first-mentioned month, the other in July.

The young birds resemble the female, and do not acquire their black head until the spring following their first winter.

The figures are of the natural size. The plant is the Carex riparia. 


\section{$2 \mathrm{BHL}$ Biodiversity Heritage Library}

Gould, John. 1873. "Reed-Bunting, Schœnicola arundinacea [PI. 29]." The birds of Great Britain 3, -. https://doi.org/10.5962/p.323920.

View This Item Online: https://www.biodiversitylibrary.org/item/221726

DOI: https://doi.org/10.5962/p.323920

Permalink: https://www.biodiversitylibrary.org/partpdf/323920

\section{Holding Institution}

Smithsonian Libraries

\section{Sponsored by}

Biodiversity Heritage Library

\section{Copyright \& Reuse}

Copyright Status: Public domain. The BHL considers that this work is no longer under copyright protection.

This document was created from content at the Biodiversity Heritage Library, the world's largest open access digital library for biodiversity literature and archives. Visit BHL at https://www.biodiversitylibrary.org. 